\title{
Pengendalian Superoxide Dismutase (SOD) dan Nitrit Oxide (NO) pada penderita DMT2 dengan emping garut (Maranta arundinacea Linn) sebagai makanan selingan
}

\section{Arrowroot chips (Maranta arundinacea Linn) as a snack to control Superoxide Dismutase (SOD) activity and Nitrit Oxide (NO) production in patients with type 2 DM}

Betty Prastuti', Sunarti ${ }^{2}$

\begin{abstract}
Backgound: Hyperglycemia in diabetes mellitus increases the production of superoxide that cause oxidative stress and decrease the activity of superoxide dismutase (SOD). SOD enzyme reduces superoxide to hydrogen peroxide to lessen the reaction between superoxide and nitric oxide (NO). To reduce hyperglycemia in diabetes mellitus, diabetics are encouraged to consume diet with low glycemic index. Arrowroot chips is a product commonly used by the community as a snack. Arrowroot has low glycemic index (glycemic index =14) so it can be used as an alternative snack for diabetics.

Objective: The aim of this study is to determine the beneficial effects of arrowroot chips to help controlling the blood glucose level, SOD activity and NO concentration in type 2 diabetes.

Methods: This is a quasi-experimental research with a one group pre test - post test. Subjects were 14 patients with type 2 diabetes mellitus who regularly visited endocrine polyclinic of RSUP.Dr. Sardjito Yogyakarta. The inclusion criteria were: aged 35-60 years, had suffered from diabetes mellitus for at least one year and currently on insulin injection therapy. The subjects were given 20 grams/day arrowroot chips to be consumed as a snack for four weeks. The blood samples were drawn before and after treatment. Glucose level were analyzed by GOD-PAP method, SOD activity was determined by Ransod kits and NO concentration was analyzed by colorimetric Gies reagent system. Finally, data were analyzed by paired t-test and correlation regression test.

Results: There was an increased glucose level from 124,43 $\pm 33,56$ to 139,00 $\pm 67,96 \mathrm{mg} / \mathrm{dl}$ after treatment $(p=0,551)$, SOD activity decreased from $77,09 \pm 19,33$ to $43,99 \pm 17,45 \mathrm{unit} / \mathrm{ml}$ whole blood after treatment $(p=0,000)$, decreased NO concentration from 1,28 $\pm 1,32$ to $1,15 \pm 0,577 \mu \mathrm{M}$ after treatment $(p=0,875)$, and a positive correlation between $S O D$ activity and NO concentration ( $\left.p=0,151 ; r=0,405 ; R^{2}=0,164\right)$.

Conclusion: Arrowroot chips consumption as a snack for 4 weeks was unable to help controlling the fasting plasma glucose level, SOD activity and NO concentration in type 2 diabetics.
\end{abstract}

KEY WORDS hyperglycemia, arrowroot chips, fasting plasma glucose, SOD, NO, DM

\begin{abstract}
ABSTRAK
Latar belakang: Hiperglikemia pada diabetes mellitus (DM) meningkatkan produksi superoksida yang menyebabkan stres oksidatif dan penurunan aktivitas superoxide dismutase (SOD). Enzim SOD mampu mereduksi superoksida menjadi hidrogen peroksida sehingga dapat mengurangi reaksi superoksida dengan nitric oxide (NO). Dalam usaha menurunkan hiperglikemia pada DM, maka penderita DM dianjurkan untuk melakukan diit dengan indeks glikemik yang rendah. Emping garut merupakan produk olahan garut yang biasa digunakan oleh masyarakat sebagai makanan selingan. Garut memiliki indeks glikemik yang rendah yaitu 14 sehingga dapat digunakan sebagai alternatif makanan selingan bagi penderita DM.

Tujuan: Penelitian ini bertujuan untuk mengetahui manfaat emping garut sebagai pengendali kadar glukosa darah, aktivitas SOD, dan kadar NO pada penderita diabetes mellitus tipe 2 (DMT2).

Metode: Penelitian ini menggunakan rancangan penelitian eksperimen semu (Quasi experiment) dengan one goup pre test - post test. Subjek penelitian adalah 14 pasien DMT2 yang secara rutin memeriksakan diri ke poli penyakit dalam RSUP Dr. Sardjito Yogyakarta dengan kriteria umur 35-60 tahun, telah menderita DM lebih dari atau sama dengan 1 tahun, dan menjalani terapi injeksi insulin. Subjek diberikan perlakuan konsumsi $20 \mathrm{~g}$ emping garut/hari sebagai makanan selingan selama 4 minggu. Sampel darah diambil sebelum dan setelah perlakuan. Analisis gula darah puasa (GDP) dilakukan dengan metode GOD-PAP, aktivitas SOD menggunakan kit Ransod, dan kadar NO dengan sistem reagen Gies. Analisa data dilakukan dengan Paired t-test dan regesi korelasi.

Hasil: Hasil penelitian menunjukkan adanya peningkatan kadar GDP yaitu 124,43 $\pm 33,56$ to $139,00 \pm 67,96 \mathrm{mg} / \mathrm{dl}$
\end{abstract}

1 Universitas Respati Yogyakarta, Progam Studi Ilmu Gizi Fakultas Ilmu Kesehatan, Jl. Laksda Adisucipto Km 6,3 Depok, Sleman, Yogyakarta, Telp (0274) 3151363, e-mail: beut_tie@yahoo.com

${ }^{2}$ Bagian Biokimia Fakultas Kedokteran Universitas Gadajah Mada, Jl Farmako, Sekip Utara, Yogyakarta 55281, e-mail: nartyr@ugm.ac.id 
setelah perlakuan $(p=0,551)$, penurunan aktivitas $S O D$ sebesar $77,09 \pm 19,33$ to $43,99 \pm 17,45$ unit/ml whole blood setelah perlakuan ( $p=0,000$ ), penurunan kadar NO sebesar $1,28 \pm 1,32$ to $1,15 \pm 0,577 \mu \mathrm{M}$ setelah perlakuan $(p=0,875)$, serta korelasi positif antara aktivitas SOD dengan kadar $N O\left(p=0,151 ; r=0,405 ; R^{2}=0,164\right)$.

Kesimpulan: Konsumsi emping garut sebagai makanan selingan selama 4 minggu tidak dapat mengendalikan kadar GDP, aktivitas SOD, dan kadar NO penderita DM tipe 2.

KATA KUNCI: hiperglikemia, emping garut, GDP, SOD, NO, DM

\section{PENDAHULUAN}

Prevalensi diabetes mellitus tipe 2 (DMT2) cenderung mengalami peningkatan diberbagai penjuru dunia. World Health Organization (WHO) memprediksi kenaikan jumlah pasien diabetes melitus (DM) di Indonesia dari 8,4 juta orang pada tahun 2000 menjadi sekitar 21,3 juta pada tahun 2030 (1). Diabetes melitus adalah suatu sindrom dengan gangguan metabolisme karbohidrat, lemak, dan protein yang disebabkan oleh berkurangnya sekresi insulin atau penurunan sensitivitas jaringan terhadap insulin sehingga terjadi hiperglikemia (2).

Hiperglikemia merupakan faktor penting dalam patogenesis komplikasi vaskuler diabetik (3), serta meningkatkan stres oksidatif melalui peningkatan produksi reactive oxygen species (ROS) (4). Hiperglikemia mempengaruhi parameter-parameter biokimia dan perkembangan penyakit jantung koroner serta angka kematian pada pasien diabetes (5). Stres oksidatif yang disebabkan oleh hiperglikemia berpengaruh pada komplikasi DM. Tingginya kadar glukosa darah dapat meningkatkan kadar ROS melalui rantai transportasi elektron di mitokondria. Transfer elektron melalui kompleks di mitokondria akan menghasilkan gradien proton sehingga terjadi perbedaan potensial elektrokimia yang akan meningkatkan produksi superoksida (6).

Peningkatan produksi ROS menyebabkan penurunan aktivitas superoxide dismutase (SOD). Kemampuan SOD merubah superoksida menjadi hidrogen peroksida mempengaruhi keseimbangan antara ROS dalam dinding vaskuler dengan produksi nitric oxide (NO) oleh endothelial nitric oxide synthase (eNOS), sedangkan bioaviabilitas NO sebagai endotelium-dependent relaxing factor tergantung pada keadaan keseimbangan tersebut (7). Penurunan pengeluaran dan aktivitas NO dapat menyebabkan kelainan vasodilator tergantung endotel (3). NO berperan menghambat aktivasi trombosit, membatasi inflamasi dengan menurunkan adhesi leukosit terhadap endotel, mencegah migrasi leukosit menuju dinding pembuluh darah, dan mengurangi proliferasi dan migrasi sel otot polos vaskular. Sifat-sifat NO ini menghambat proses aterogenesis dan melindungi pembuluh darah $(8,9)$.

Penderita DM dianjurkan untuk diit dengan makanan yang mengandung indeks glikemik (IG) rendah sebagai sumber karbohidrat. Diit dengan IG rendah merupakan faktor penting dalam pencegahan risiko metabolik (1). Diit dengan indeks glikemik rendah memberikan beberapa manfaat antara lain menurunkan berat badan dengan cepat, menurunkan gula darah puasa dan kadar insulin, menurunkan kadar trigliserida yang tersirkulasi serta memperbaiki tekanan darah, menurunkan inflamasi dan disfungsi endotel sehingga akan menurunkan faktor risiko kardiovaskuler (10). Umbi garut jika dibandingkan dengan roti tawar sebagai standar, memiliki indeks glikemik 14 yang merupakan nilai terendah di antara umbi-umbian lokal lainnya. Ubi jalar memberikan indeks glikemik tertinggi yaitu 179 , kimpul, gembili, dan ganyong memiliki indeks glikemik berturut-turut 95, 90, dan 105. Sehingga garut dapat digunakan sebagai alternatif makanan fungsional untuk diit bagi penderita DM (11). Salah satu pemanfaatan garut oleh masyarakat adalah dalam bentuk emping. Emping garut memiliki kadar serat $80 \%$, protein $5 \%$, dan kalori $347,99 \%$ (12).

Sehingga perlu dilakukan penelitian pengaruh emping garut (Maranta arundinacea Linn) terhadap kadar glukosa plasma puasa, aktivitas SOD, kadar NO serta hubungan aktivitas SOD dengan kadar NO penderita DMT2 yang telah diberi perlakuan emping garut untuk memberikan landasan ilmiah manfaat penggunaan emping garut bagi penderita diabetes.

\section{BAHAN DAN METODE}

Penelitian ini menggunakan desain penelitian eksperimen semu (quasi experiment) dengan one goup pre test - post test. Penelitian ini dilakukan bulan Juni sampai Agustus 2010 dengan pemberian perlakuan emping garut selama 4 minggu di RSUP Dr.Sardjito Yogyakarta, sedangkan emping garut yang digunakan dalam penelitian ini adalah produksi kelompok tani binaan Dinas Perindustrian Kabupaten Sragen dengan kadar serat $80 \%$, protein $5 \%$, dan kalori $347,99 \%$ (12). Pemeriksaan glukosa darah puasa, SOD, dan NO dilakukan di Laboratorium Biokimia Fakultas Kedokteran Universitas Gadjah Mada.

Subjek penelitian adalah pasien DMT2 yang melakukan kontrol rutin di poliklinik endokrinologi RSUP Dr Sardjito Yogyakarta. Kriteria inklusi subjek penelitian adalah wanita penderita DMT2, umur 35-60 tahun, terdiagnosa DMT2 lebih dari atau sama dengan 1 tahun, menjalani terapi insulin (injeksi), dan bersedia menjadi subjek penelitian. Kriteria eksklusi subjek penelitian adalah obesitas (body mass index/BMI $\geq 30$ ), merokok, 
dan sedang hamil. Besar sampel dihitung dengan menggunakan rumus sampel tunggal untuk perkiraan rerata (13) dengan tingkat kemaknaan $(Z \alpha)=1,96$; simpang baku nilai rerata dalam populasi $(S)=0,96$ (14); dan ketepatan absolut $(d)=0,5$. Berdasarkan rumus tersebut diperoleh jumlah sampel minimal penelitian (n) adalah 14, ditambah dengan kemungkinan tidak terikuti $25 \%$ (loss to follow-up 25\%) yaitu 4 sampel, sehingga jumlah sampel minimal menjadi 18 pasien.

Subjek yang diperoleh pada awal pelaksanaan penelitan adalah 60 pasien DMT2 yang memungkinkan untuk dijadikan sebagai subjek penelitian, tetapi hanya 19 pasien yang diambil sebagai subjek penelitian dengan pertimbangan BMI, kesediaan mengikuti penelitian, dan riwayat anamnesis gizi yang dilakukan oleh petugas gizi sehingga pasien tersebut diperkirakan tidak dapat mematuhi konsumsi emping garut. Lima dari 19 subjek penelitian ini tidak dapat menyelesaikan penelitian dengan beberapa alasan yaitu, 1 subjek mengundurkan diri saat perlakuan, 2 subjek tidak dapat hadir ketika dilakukan pengambilan sampel darah yang terakhir, serta 2 subjek hanya mengonsumsi $53,57 \%$ dan $43,75 \%$ emping garut yang diberikan sehingga 2 subjek tersebut termasuk mengalami defisit dalam klasifikasi tingkat konsumsi perorangan. Subjek penelitian yang dapat dianalisis hanya 14 subjek yang mengonsumsi emping garut dengan kriteria sedang dan baik. Tingkat konsumsi emping garut diklasifikasikan menjadi: baik jika konsumsi sama dengan $100 \%$ emping garut yang diberikan; sedang jika konsumsi lebih dari 80\%; kurang jika konsumsi $70-80 \%$; dan defisit jika konsumsi kurang dari $70 \%$ emping garut yang diberikan.

Variabel bebas adalah makanan selingan dengan IG rendah yaitu emping garut. Emping garut digoreng menggunakan teknik sangrai dengan menggunakan media pasir untuk menghindari pengaruh minyak goreng dalam komposisi gizinya. Variabel tergantung adalah kadar glukosa plasma puasa, aktivitas SOD, dan kadar NO. Berdasarkan perhitungan kebutuhan gizi dan seratnya, subjek penelitian diberikan redukasi untuk menjalankan diit DM 1500 kkal dengan jumlah energi 1500 kkal/hari, karbohidrat $225 \mathrm{~g} /$ hari, protein $52 \mathrm{~g} /$ hari, lemak $42 \mathrm{~g} / \mathrm{hari}$ serta serat $25 \mathrm{~g} / \mathrm{hari}$. Standar diit ini digunakan untuk menentukan tingkat konsumsi dan kepatuhan subjek terhadap diit yang dilakukan. Reedukasi memberikan informasi pada subjek penelitian untuk menyamakan persepsi mengenai jumlah, jenis, dan jadwal yang harus dipatuhi dalam menjalankan diit DM yang pernah didapatkan sebelumnya.

Calon subjek diukur tinggi badan dan berat badannya terlebih dahulu. Apabila memenuhi kriteria inklusi dan bersedia ikut serta dalam penelitian, calon subjek diminta mengisi dan menandatangani form informed consent. Subjek diambil darahnya sebanyak $5 \mathrm{ml}$ oleh perawat (dengan kualifikasi pendidikan S1) untuk pemeriksaan kadar glukosa darah, aktivitas SOD, kadar NO serta kadar kolesterol total dan trigliserida. Kadar glukosa darah puasa (GDP dalam mg/dl) sebelum dan setelah pemberian emping garut diukur setelah puasa minimal 8 jam sebelum pengambilan darah dan ditentukan secara kolorimetri oleh peneliti dengan metode glucose oxydase-p-amino phenazone (GOD PAP). Aktivitas SOD eritrosit (unit/ml whole blood) dan jumlah NO dalam plasma ( $\mathrm{mmol} / \mathrm{L}$ ) sebelum dan setelah pemberian emping garut ditentukan secara kolorimetri.

Berdasarkan evaluasi food record diketahui bahwa $82,35 \%$ responden memiliki asupan serat defisit (50\%) sehingga asupan rata-rata $12,8 \mathrm{~g}$ serat/hari. Oleh karena itu emping garut yang diberikan sebesar 15,25 g (20 g/hari) untuk mendapatkan asupan serat sebesar 12,2 g guna memenuhi kebutuhan serat hingga $25 \mathrm{~g} /$ hari. Pemberian perlakuan emping garut $20 \mathrm{~g} /$ hari dilaksanakan setiap hari selama 4 minggu. Dalam penelitian ini juga dilakukan survei konsumsi makanan oleh peneliti dengan menggunakan form food record. Subjek penelitian diwajibkan mencatat seluruh makanan yang dikonsumsi selama 3 hari, dimulai pada 1 bulan sebelum penelitian, yaitu sebelum pasien diberikan reedukasi mengenai diit DM, kemudian setelah reedukasi tetapi belum diberikan perlakuan, dan 2 minggu setelah perlakuan. Hal ini dimaksudkan untuk mengetahui kebiasaan dan kepatuhan subjek penelitian dalam melakukan diit yang dianjurkan. Selain itu subjek penelitian juga diminta untuk mencatat jumlah emping garut yang dikonsumsi dengan cara mengisi form yang telah disediakan oleh peneliti. Hasil survei konsumsi makanan dan konsumsi emping garut dianalisa dengan program nutrisurvey.

Data karakteristik subjek disajikan dalam jumlah persentase dan angka rerata. Analisis untuk melihat perbedaan sebelum dan setelah perlakuan dilakukan dengan paired t test. Analisis regresi korelasi untuk melihat hubungan dua variabel serta mengetahui keeratan hubungan tersebut. Penelitian ini telah mendapatkan persetujuan dari Komite Etik Penelitian Kedokteran dan Kesehatan Fakultas Kedokteran Universitas Gadjah Mada.

\section{HASIL}

Subjek penelitian ini adalah 14 pasien DM tipe 2 dengan jenis kelamin perempuan yang melakukan kontrol rutin di poliklinik endokrinologi RSUP Dr Sardjito Yogyakarta. Karakteristik subjek penelitian ditunjukkan dalam Tabel 1.

Asupan emping garut yang rendah pada 2 subjek disebabkan subjek merasa sebah setelah mengonsumsi emping garut dan pada satu subjek lainnya menghentikan konsumsi emping garut karena kondisi batuk. Sehingga 
Tabel 1. Karakteristik subjek penelitian

\begin{tabular}{|c|c|c|}
\hline $\begin{array}{c}\text { Karakteristik } \\
(n=14)\end{array}$ & Rerata \pm SD & $\begin{array}{c}\text { Median } \\
\text { (Min - Maks) } \\
\end{array}$ \\
\hline Umur (th) & $55,79 \pm 2,259$ & $55(52-59)$ \\
\hline TB (cm) & $155,43 \pm 5,32$ & $156(144-165)$ \\
\hline $\mathrm{BB}(\mathrm{kg})$ & $64,54 \pm 6,62$ & $66,5(54-74)$ \\
\hline Lama DM (th) & $7,71 \pm 5,915$ & $6,5(1-24)$ \\
\hline BMI & $26,70 \pm 2,35$ & $26,55(22,4-30,40)$ \\
\hline Normal $(n, \%)$ & $3(21,4)$ & \\
\hline Overweight $(\mathrm{n}, \%)$ & $10(71,4)$ & \\
\hline Obesitas $(n, \%)$ & $1(7,10)$ & \\
\hline
\end{tabular}

subjek penelitian yang dapat dianalisis hanya 14 subjek yang mengonsumsi emping garut dengan kriteria sedang dan baik. Empat belas subjek penelitian tersebut tidak mengalami kesulitan dan keluhan selama mengonsumsi emping garut, akan tetapi beberapa subjek mengatakan bahwa selama mengonsumsi emping garut harus disertai dengan minum air putih agar emping garut lebih mudah ditelan. Berdasarkan hasil penelitian, 13 subjek penelitian termasuk dalam kategori baik untuk konsumsi emping garut yaitu dengan mengonsumsi $100 \%$ emping garut yang diberikan, sedangkan satu subjek penelitian mengonsumsi $97,68 \%$ emping garut yang diberikan sehingga termasuk dalam kategori sedang.

Subjek penelitian diberikan informasi dengan reedukasi untuk menyamakan persepi mengenai jumlah, jenis, dan jadwal yang harus dipatuhi dalam menjalankan diit DM yang pernah didapatkan sebelumnya. Reedukasi dilakukan setelah kebutuhan kalori dan zat gizi subjek penelitian dihitung sesuai dengan rekomendasi Perkumpulan Endokrinologi Indonesia (PERKENI) (1). Perbandingan konsumsi zat gizi subjek penelitian sebelum dan setelah perlakuan ditunjukkan dalam Tabel 2. Asupan

Tabel 2. Perbandingan konsumsi energi, lemak, protein, dan serat sebelum dan setelah perlakuan

\begin{tabular}{|c|c|c|c|}
\hline Zat gizi & $\begin{array}{c}\text { Sebelum perlakuan } \\
\text { Mean } \pm \text { SD }\end{array}$ & $\frac{\text { Setelah perlakuan }}{\text { Mean } \pm \text { SD }}$ & p (Cl 95\%) \\
\hline Energi (kkal) & $1185,55 \pm 223,62$ & $1206,9 \pm 303,54$ & $\begin{array}{c}0,791^{\mathrm{a}} \\
(-91,57 ; 148,85)\end{array}$ \\
\hline $\mathrm{KH}$ (g/hari) & $182,64 \pm 44,08$ & $167,04 \pm 46,96$ & $\begin{array}{c}0,201^{\mathrm{a}} \\
(-9,41 ; 40,61)\end{array}$ \\
\hline Lemak (g/hari) & $34,01 \pm 11,41$ & $35,88 \pm 13,14$ & $\begin{array}{c}0,601^{a} \\
(-9,41 ; 5,66)\end{array}$ \\
\hline Protein (g/hari) & $40,26 \pm 12,70$ & $39,63 \pm 11,49$ & $\begin{array}{c}0,853^{a} \\
(-6,61 ; 7,78)\end{array}$ \\
\hline Serat (g/hari) & $12,08 \pm 3,82$ & $32,243 \pm 21,93$ & $0,001^{\mathrm{b}^{* *}}$ \\
\hline
\end{tabular}

Keterangan: $\mathrm{a}=$ distribusi data normal,menggunakan uji paired $t$ test $\mathrm{b}=$ distribusi data tidak normal, menggunakan uji Wilcoxon ** $=$ signifikan dengan uji Wilcoxon $(p<0,05)$

Tabel 3. Perbandingan BB, BMI, kadar GDP, aktivitas SOD, kadar NO, trigliserida, dan kolesterol total subjek penelitian sebelum dan setelah perlakuan

\begin{tabular}{|c|c|c|c|}
\hline Hasil & $\begin{array}{c}\text { Sebelum perlakuan } \\
\text { Mean } \pm \text { SD }\end{array}$ & $\begin{array}{c}\text { Setelah perlakuan } \\
\text { Mean } \pm \text { SD }\end{array}$ & $\mathrm{p}(\mathrm{Cl}$ 95\%) \\
\hline $\mathrm{BB}(\mathrm{kg})$ & $64,54 \pm 6,62$ & $63,57 \pm 5,94$ & $\begin{array}{c}0,016^{a^{*}} \\
(0,2092 ; 1,719)\end{array}$ \\
\hline BMI $\left(\mathrm{kg} / \mathrm{m}^{2}\right)$ & $26,70 \pm 2,34$ & $26,31 \pm 2,17$ & $\begin{array}{c}0,017^{a^{*}} \\
(0,081 ; 0,690)\end{array}$ \\
\hline GDP (mg/dl) & $124,43 \pm 33,56$ & $139,00 \pm 67,96$ & $0,551^{\mathrm{b}}$ \\
\hline SOD (unit/ml whole blood) & $77,09 \pm 19,33$ & $43,99 \pm 17,45$ & $\begin{array}{c}0,000^{a^{*}} \\
(18,59 ; 47,60)\end{array}$ \\
\hline $\mathrm{NO}(\mu \mathrm{M})$ & $1,28 \pm 1,32$ & $1,15 \pm 0,57$ & $0,875^{\mathrm{b}}$ \\
\hline Trigliserida $(\mathrm{mg} / \mathrm{dl})$ & $88,93 \pm 28,73$ & $113,28 \pm 43,11$ & $0,013^{b^{* *}}$ \\
\hline Kolesterol total (mg/dl) & $180,21 \pm 53,93$ & $160,57 \pm 36,67$ & $0,300^{\mathrm{b}}$ \\
\hline
\end{tabular}

Keterangan: $\mathrm{BB}=$ berat badan

$\mathrm{BMI}=$ body mass index

GDP = gula darah puasa

$\mathrm{SOD}=$ superoxide dismutase

$\mathrm{NO}=$ nitrit oxide

a = distribusi data normal, menggunakan paired t test

$\mathrm{b}=$ distribusi data tidak normal, menggunakan uji Wilcoxon

* $=$ signifikan dengan paired t test $(p<0,05)$

** $=$ signifikan dengan uji Wilcoxon $(p<0,05)$ 
energi, karbohidrat, lemak, dan protein subjek penelitian lebih rendah dari standar diit 1500 kkal. Sedangkan asupan serat mengalami peningkatan setelah perlakuan pemberian emping garut.

Setelah diberikan perlakuan, terjadi penurunan aktivitas SOD yang signifikan, sedangkan peningkatan GDP dan penurunan kadar NO tidak signifikan (Tabel 3). Selain itu terlihat penurunan berat badan (BB) dan body mass index (BMI) serta peningkatan kadar trigliserida yang signifikan, sedangkan penurunan kadar kolesterol tidak signifikan. Konsumsi emping garut berkorelasi secara positif yang sangat lemah $(r=0,122)$ dan tidak signifikan $(p=0,678)$ dengan GDP. Sedangkan konsumsi emping garut dengan SOD berkorelasi secara negatif sangat lemah $(r=-0,092)$ dan tidak signifikan $(p=0,560)$. Konsumsi emping garut dengan kadar NO berkorelasi negatif yang lemah $(r=-0,094)$ dan tidak signifikan $(p=0,750)$. Aktivitas SOD dengan NO berkorelasi positif sedang $(r=0,405)$ namun tidak signifikan $(p=0,151)$.

\section{BAHASAN}

\section{Pengaruh emping garut (Maranta arundinacea Linn) terhadap kadar GDP penderita DMT2}

Hasil penelitian ini menunjukkan pemberian emping garut selama 1 bulan kepada 14 responden belum memberikan pengaruh terhadap GDP $(p=0,551)$. Hasil uji korelasi konsumsi emping garut dengan kenaikan kadar glukosa darah menunjukan arah yang positif dan sangat lemah $(r=0,127)$ tetapi tidak signifikan $(p=0,665)$ dan nilai $R^{2}=0,016$. Artinya emping garut memberikan pengaruh terhadap kenaikan kadar glukosa darah hanya sebesar 1,6\% dan 98,4\% kenaikan kadar glukosa darah dipengaruhi oleh faktor lain.

Hal ini dapat terjadi karena terdapat 2 subjek penelitian dengan peningkatan kadar glukosa darah yang tinggi setelah pemberian emping garut yaitu dari $90 \mathrm{mg} / \mathrm{dl}$ menjadi 248 mg/dl dan 197 mg/dl menjadi 320 mg/dl karena 2 subjek penelitian tersebut tidak mematuhi dosis insulin dan diit yang direkomendasikan. Jika kedua subjek tersebut dieksklusi, rata-rata GDP sebelum dan setelah pemberian emping garut adalah 121,25 mg/dl dan 114,83 mg/dl sehingga terlihat adanya penurunan kadar GDP, meskipun demikian penurunan kadar GDP tersebut tidak signifikan $(p=0,470)$.

Faktor yang mempengaruhi peningkatan kadar glukosa darah tidak hanya berasal dari pencernaan dan absorbsi makanan yang mengandung karbohidrat, melainkan juga berasal dari proses glukoneogenesis dan glikogenolisis. Saat karbohidrat tidak tersedia cukup dalam makanan maka senyawa non karbohidrat dengan jalur glukoneogenesis akan menghasilkan glukosa. Glukoneogenesis merupakan proses mengubah prekursor non karbohidrat menjadi glukosa atau glikogen dengan substrat utama asam-asam amino glukogenik, laktat, gliserol, dan propionat. Dalam penelitian ini asupan zat gizi karbohidrat, protein, dan lemak subjek lebih rendah dari kebutuhan zat gizi per hari subjek sehingga kemungkinan subjek penelitian mengalami peningkatan glukoneogenesis dan glikogenolisis (9).

Hasil penelitian di Amerika Serikat menyatakan bahwa naiknya kadar gukosa darah pada DM tipe 2 disebabkan oleh peningkatan glukoneogenesis dan glikogenolisis di hati. Dalam penelitiannya mengenai peningkatan glukoneogenesis pada DM tipe 2, terdapat peningkatan glukoneogenesis pada pasien diabetes sebesar 9,8 $\pm 0,7 \mu \mathrm{mol} /(\mathrm{kg}$ body wt $\mathrm{x}$ min) dibandingkan dengan kontrol sebesar $6,1 \pm 0,5 \mu \mathrm{mol} /(\mathrm{kg}$ body wt $x \min )(p<0,01)(15)$.

Peningkatan proses glukoneogenesis kemungkinan disebabkan oleh lipolisis yang terlihat dengan adanya penurunan berat badan dan BMI yang diikuti oleh peningkatan kadar trigliserida secara signifikan setelah pemberian emping garut $(p=0,013)$. Glukosa pada pasien DM tidak digunakan sebagai energi oleh jaringan sehingga terjadi hiperglikemia. Energi diperoleh dari asam lemak hasil lipolisis di jaringan adiposa dan kelebihan asam lemak akan terakumulasi di dalam hati dan dikonversi menjadi trigliserida (16). Dalam penelitian ini terjadi peningkatan kadar trigliserida yang signifikan dan berkorelasi positif dengan konsumsi emping garut.

Peningkatan asupan serat secara signifikan setelah konsumsi emping garut tidak memberikan perubahan yang bermakna terhadap kadar glukosa darah. Emping garut yang dikonsumsi sebagai makanan selingan dalam penelitian ini memiliki kandungan serat yang tinggi yaitu $80 \%$. Asupan serat setelah pemberian emping garut meningkat menjadi $32,24 \pm 21,93 \mathrm{~g}$ melebihi rekomendasi PERKENI (1) yaitu sebesar $25 \mathrm{~g} /$ hari, namun asupan serat hingga $40 \mathrm{~g} /$ hari juga direkomendasikan oleh American Diabetes Assocition (ADA) (17). Indeks glikemik berhubungan dengan respon glukosa makanan, sedangkan respon glukosa berhubungan dengan kecernaan makanan. Kadar glukosa darah menggambarkan kecernaan dan absorbsi karbohidrat, maka dapat dikatakan bahwa indeks glikemik yang rendah umumnya disebabkan oleh kecernaan yang rendah (11).

Serat yang dianjurkan untuk penderita DM adalah serat larut. Serat larut akan meningkatkan viskositas chyme, memperlambat pengosongan lambung serta lebih sulit dicerna oleh enzim (18). Serat larut air terutama pektin dan gum, mempunyai pengaruh hipoglikemik karena memperlambat pengosongan lambung, memperpendek waktu transit makanan dalam saluran cerna, dan mengurangi absorbsi glukosa (19). Tepung umbi garut memiliki kadar serat larut 5,03\% dan serat tidak larut $8,74 \%$ (7). Meskipun jenis serat dalam emping garut belum diketahui dengan pasti, dalam penelitian ini emping garut dapat memberikan sumbangan serat $51,69 \%$ dari kebutuhan subjek. Sebelum perlakuan, subjek hanya mampu memenuhi $48,21 \%$ kebutuhan seratnya. 


\section{Pengaruh emping garut (Maranta arundinacea Linn) terhadap aktivitas SOD penderita DMT2}

Aktivitas SOD mengalami penurunan yang bermakna setelah pemberian perlakuan emping garut dan hasil uji korelasi antara konsumsi emping garut dengan aktivitas SOD menunjukkan arah korelasi negatif. Meskipun demikian korelasi tersebut sangat lemah dan tidak signifikan.

Hal ini dapat terjadi karena dalam penelitian ini peningkatan asupan serat yang signifikan setelah konsumsi emping garut, secara statistik tidak dapat mengendalikan kadar glukosa darah subjek penelitian. Keadaan hiperglikemia akan meningkatkan produksi superoksida yang menyebabkan penurunan aktivitas SOD (7). SOD merupakan enzim antioksidan yang berperan dalam mengkatalisis perubahan ion superoksida yang merupakan radikal bebas menjadi hidrogen peroksida (20). Rendahnya aktivitas enzim antioksidan dapat menunjukkan tingginya kadar radikal bebas dalam tubuh (21). Hal ini disebabkan SOD tidak mampu mengimbangi peningkatan produksi superoksida. Sehingga kadar radikal bebas yang tinggi pada diabetes terjadi karena keadaan hiperglikemia (4). Aktivitas antioksidan enzimatis sangat dipengaruhi oleh asupan antioksidan non enzimatis. Penelitian membuktikan bahwa aktivitas SOD eritrosit pada kaum pria yang diberi jus tomat selama seminggu meningkat secara signifikan $(p<0,05)$. Peningkatan ini disebabkan oleh kandungan antioksidan likopen yang dapat menghambat terjadinya reaksi oksidasi (21).

Penurunan aktivitas SOD pada penderita diabetes selain disebabkan oleh peningkatan produksi superoksida juga karena terjadi peningkatan proses glikasi lisin dalam protein enzim. Proses glikasi yang meningkat ini diperkuat oleh adanya produksi fruktosa sebagai agen glikasi yang reaktif melalui peningkatan jalur poliol (22).

\section{Pengaruh emping garut (Maranta arundinacea Linn) terhadap kadar NO dan kolesterol total penderita DMT2}

Setelah diberikan perlakuan dengan emping garut, kadar NO subjek penelitian mengalami penurunan meskipun tidak signifikan dan hasil uji korelasi antara konsumsi emping garut dengan kadar NO menunjukkan arah korelasi negatif sangat lemah dan tidak signifikan.

Penurunan kadar NO kemungkinan disebabkan oleh penurunan aktivitas SOD. Penurunan kemampuan SOD dalam merubah superoksida menjadi hidrogen peroksida mempengaruhi keadaan keseimbangan antara ROS dalam dinding vaskuler dengan produksi NO oleh eNOS (7). Nitrit oksida dapat bereaksi dengan superoksida membentuk peroksinitrit sehingga terjadi penurunan NO (23).

Dalam penelitian ini terjadi penurunan kadar kolesterol total yang tidak signifikan setelah pemberian emping garut. Keadaan hiperkolesterolemia mempengaruhi aktivitas eNOS dengan menginduksi ekspresi dan aktivitas eNOS sebagai enzim yang mengkatalisis biosintesis NO (24). Pembentukan NO oleh eNOS dalam endotelium dipengaruhi oleh lipid sebagai regulator potensial (25).

Penurunan kadar kolesterol total berhubungan dengan konsumsi serat (26). Penurunan kadar kolesterol terkait dengan metabolisme asam empedu. Asam empedu dan steroid netral disintesis dalam hati dari kolesterol, disekresi ke dalam empedu dan kembali ke hati melalui reabsorpsi dalam usus halus (siklus enterohepatik). Serat makanan diduga menghalangi siklus ini dengan menyerap asam empedu sehingga perlu diganti dengan asam empedu baru dari kolesterol persediaan, sehingga terjadi penurunan kadar kolesterol (2). Hal ini didukung oleh hasil penelitian di Palembang yang menyatakan bahwa terdapat hubungan antara asupan serat, vitamin B3, vitamin $\mathrm{C}$, dan vitamin $\mathrm{E}$ terhadap profil kolesterol total darah. Asupan serat, vitamin B3, C, dan E di bawah 90\% angka kecukupan gizi (AKG) berisiko 5 kali lebih besar untuk memiliki kadar kolesterol total tinggi bila dibandingkan dengan orang yang mempunyai pola konsumsi di atas $90 \%$ AKG (27).

\section{Hubungan aktivitas SOD dengan kadar NO penderita DMT2 yang telah diberi perlakuan emping garut (Maranta arundinacea Linn)}

Hasil uji korelasi aktivitas SOD terhadap kadar NO menunjukkan korelasi positif dengan kekuatan sedang $(r=0,405)$ tetapi tidak signifikan $(p=0,151)$ dan nilai $\mathrm{R}^{2}=0,164$ sehingga aktivitas SOD memberikan pengaruh sebesar $16,4 \%$ terhadap kadar NO.

Penurunan kadar NO tidak hanya dipengaruhi oleh aktivitas SOD, tetapi juga dapat disebabkan oleh peningkatan inhibitor endogen eNOS yaitu asymetric dimethylarginin (ADMA). Peningkatan konsentrasi ADMA menghambat eNOS dalam memproduksi NO (28).

Sintesis NO oleh eNOS membutuhkan tetrahydrobiopterin (BH4) sebagai kofaktor. Konsentrasi $\mathrm{BH} 4$ akan menurun jika superoksida meningkat pada hiperglikemia sehingga terjadi eNOS uncoupling (29). Jika terjadi eNOS uncoupling, nicotine adenine dinucleotide phosphate hydrogen (NADPH) tidak bereaksi dengan L-arginin untuk menghasilkan NO tetapi bereaksi dengan oksigen, sehingga sel endotel lebih banyak menghasilkan superoksida daripada NO (30). Peningkatan produksi advanced glycation endproduct (AGE) yang jika berikatan dengan reseptornya maka AGE akan menghambat fosforilasi eNOS sehingga menghambat produksi NO (31).

Dalam penelitian ini pemberian emping garut sebagai makanan selingan dalam waktu 1 bulan (4 minggu) tidak dapat mengendalikan kadar GDP, aktivitas SOD, dan kadar NO penderita DM tipe 2. Peningkatan kadar glukosa darah akan meningkatkan pembentukan superoksida sebagai 
radikal bebas. Jumlah superoksida yang meningkat mempengaruhi kemampuan SOD dalam menetralkan radikal bebas oksigen tersebut sehingga terjadi penurunan aktivitas SOD. Keadaan ini memungkinkan superoksida bereaksi dengan NO membentuk peroksinitrit sehingga terjadi penurunan kadar NO. Kadar NO yang menurun dalam penelitian ini juga dipengaruhi oleh penurunan kadar kolesterol karena dalam jangka pendek kolesterol akan menjaga aktivitas eNOS sebagai enzim yang mengkatalisis pembentukan NO.

\section{KESIMPULAN DAN SARAN}

Konsumsi emping garut sebagai makanan selingan selama 4 minggu tidak dapat mengendalikan kadar GDP, aktivitas SOD, dan kadar NO penderita DM tipe 2 yang ditunjukkan dengan adanya peningkatan kadar GDP $(p=0,551)$, penurunan aktivitas SOD $(p=0,000)$ serta penurunan kadar NO $(p=0,875)$.

Oleh karena itu perlu dilakukan penelitian sejenis dalam waktu yang lebih lama dengan mempertimbangkan proses penurunan berat badan (BB) sampai tercapai berat badan ideal (BBI). Sesuai rekomendasi PERKENI (2006) dengan mengurangi asupan energi $20-30 \%$ dari total kalori per hari tergantung pada tingkat kegemukan subjek penelitian dan jumlah kalori yang diberikan paling sedikit 1000-1200 kkal/hari untuk subjek perempuan. Berdasarkan data BB dan tinggi badan (TB) subjek penelitian ini, maka BBI yang seharusnya dicapai adalah (TB-100)-10\%(TB-100) $=49,88 \mathrm{~kg}$, sehingga kelebihan BB subjek penelitian sebesar 64,54-49,88=14,66 $\mathrm{kg}$. Berat badan ideal subjek penelitian diperkirakan dapat dicapai dalam waktu 29,32 sampai 48,87 minggu dengan pengurangan berat badan sebesar $0,3-0,5 \mathrm{~kg} /$ minggu dan jumlah kalori yang diberikan paling sedikit 1000-1200 kkal/ hari sesuai dengan kebutuhan energi masing-masing subjek penelitian.

\section{RUJUKAN}

1. PERKENI. Konsensus pengelolaan dan pencegahan diabetes mellitus tipe 2 di Indonesia 2006. Jakarta: Pengurus Besar Perkumpulan Endokrinologi Indonesia (PB.PERKENI); 2006.

2. Guyton $A C$, Hall JE. Buku ajar fisiologi kedokteran edisi 11. Irawati (Alih bahasa). Jakarta: EGC; 2006.

3. Suastika K. Peranan hiperglikemia dalam terjadinya komplikasi kronik diabetes melitus. Majalah Kedokteran Udayana 2000;31(110):182-8.

4. Roberston RP, Harmon J, Tran PO, Tanaka Y, Takahashi H. Glucose toxicity in $\beta$-cell: type 2 diabetes, good radical gone bad, and the glutathione connection. Diabetes 2003;52:581-7.

5. Mahfouz MH, Emara IA, Shouman MS, Ezz MK. Asymetrical dimethylaginine (ADMA) and nitric oxide as potential cardiovascular risk factors in type 2 diabetes mellitus. Afr J Biochem Res 2009;3(8):293-301.

6. Brownlee M. Biochemistry and molecular cell biology of diabetic complications. Nature 2001;414(6865):81320.

7. Schiffrin EL. Oxidative stress, nitric oxide synthase, and superoxide dismutase a matter of imbalance underlies endhthelial dysfunction in the human coronary circulation. Hypertension 2008;51:31-3.

8. American Diabetes Association. Standards of medical care in diabetes-2008. Diabetes Care 2008;31(Suppl 1):S12-54.

9. Beckman JA, Creager MA, Libby P. Diabetes and atherosclerosis: epidemiology, pathophysiology, and management. JAMA 2002;287(19):2570-81.

10. Radulian G, Rusu E, Dragomir A, Posea M. Metabolic effects of low glycaemic index diets. J Nutr 2009;8:5.

11. Marsono $Y$, Wiyono $P$, Utomo Z. Indeks glikemik garut (Maranta arundinace $L$ ) dan uji sifat fungsionalnya pada model hewan coba. Jakarta: Kementrian Ristek: Laporan akhir penelitian rusnas diversifikasi pangan pokok; 2005.

12. POK LIMBI. Emping garut makanan sehat masa depan. Yogyakarta: Pusat Studi Pangan Dan Gizi Universitas Gadjah Mada; 2008.

13. Sastroasmoro S, Ismael S. Dasar-dasar metodologi penelitian klinis. Jakarta: Bina Rupa Aksara; 2008.

14. Jenkins DA, Wolever TMS, Buckley G, Lam KY, Giudici S, Kalmusky J, Jenkins AL, RL Patten, Bird J,Wong GS. Low-glycemic-index starchy foods in the diabetic diet. Am J Clin Nutr 1988;48(2):248-54.

15. Magnusson I, Rothman DL, Katz L, Shulman RG, Shulman GI. Increased rate of gluconeogenesis in type II diabetes mellitus. A $13 \mathrm{C}$ nuclear magnetic resonance study. J Clin Invest 1992;90(4):1323-7.

16. Suryawanshi NP, Bhuthey AK, Nagdeote AN, Jadhav AA, Manoorkar GS. Study of lipid peroxide and lipid profile in diabetes mellitus. Indian $\mathrm{J}$ Clin Biochem 2006;21(1):126-30.

17. Katz DL. Nutrition in clinical practice. Conecticut: Lippinncot Williams \& Wilkins; 2000.

18. DeBruyne LK, Pinna K, Whitney E. Nutrition and diet therapy, principle and practice. USA: Wadsworth; 2008.

19. Almatsier S. Prinsip dasar ilmu gizi. Jakarta: PT Gramedia Pustaka Utama; 2002.

20. Murray RK, Ganner DK, Rodwell VW. Biokimia Harper. Pendit BU (Alih bahasa). Jakarta: EGC; 2009.

21. Winarsi $H$. Antioksidan alami dan radikal bebas. Yogyakarta: Kanisius; 2007.

22. Nishimura $\mathrm{CY}$. Aldose reduktase in glucose toxicity: a potential target for the prevention of diabetic complications. Pharmacol Rev 1998;50(1):21-34.

23. Fang $Y Z$, Yang $S$, Wu G. Free radicals, antioxidants, and nutrition. Nutrition 2002;18(10):872-9. 
24. Norata GD, Catpano AL. Molecular mecanism responsible for the antiinflamatori and protective effect of HDL on the endothelium. Milano, Italy: Department of Pharmacological Sciene; 2005.

25. Chikani G, Zhu W, Smart EJ. Lipids: potential regulators of nitric oxide generation. Am J Physiol Endocrinol Metab 2004;287(3):E386-9.

26. Bresson JL, Flynn A, Heinonen M, Hulshof K. Dietary reference values for carbohydrates and dietary fibre. Draft Opinion of the Scientific Panel on Dietetic Products, Nutrition and Allergies on a request from the Commission related to dietary reference values for carbohydrates and dietary fibre. EFSA Journal 2009;xxx:1-76.

27. Muzakar, Dinarti K, Astuti H. Asupan vitamin B3 (niasin), vitamin $C, E$, dan serat berhubungan dengan dislipidemia pada penyakit jantung koroner di RS DR. Mohammad
Hoesin Palembang. Jurnal Gizi Klinik Indonesia 2010;6(3):114-22.

28. Sydow K, Munzel T. ADMA and oxidative stress. Atheroscler Suppl 2003;4(4):41-51.

29. Bagi Z, Toth E, Koller A, Kaley G. Microvascular dysfunction after transient high glucose is caused by superoxide-dependent reduction in the bioavailability of $\mathrm{NO}$ and $\mathrm{BH} 4$. Am J Physiol Heart Circ Physiol 2004;287(2):H626-33.

30. Hayden MR, Tyagi SC. Uric acid: a new look at an old risk marker for cardiovascular disease, metabolic syndrome, and type 2 diabetes mellitus: the urate redox shuttle. Nutr Metab 2004;1(1):10.

31. Singh R, Barden A, Mori T, Beilin L. Advanced glycation end-products: a review. Diabetologia 2001;44(2):129-46. 